\title{
The Cohesion Policy on the EU's Eastern and Southern periphery: Misallocated Funds?
}

\author{
Gergő Medve-Bálint* \\ Center for Social Sciences, Hungarian Academy of Sciences \\ Corvinus University of Budapest
}

\begin{abstract}
The cohesion policy of the European Union has become its primary instrument promoting development in the peripheral member states. The enduring consequences of the 2007-08 crisis and the economic governance agenda requiring fiscal discipline from the member states have raised the policy's significance further. However, similar economic inequalities characterize the EU nowadays as several decades ago. The cohesion policy is by no means alone responsible for this, but the reasons for its ambiguous performance deserve further scrutiny. Empirical studies explain variation in fund performance with domestic institutional quality and absorption capacity, but the member states' fund spending strategies have not been addressed so far. This is puzzling because they are important determinants of the economic effects of EU funds. The paper fills this gap by investigating the spending strategies of the Southern and the Eastern members in two recent programming cycles (2007-13 and 2014-20). Assessed on five expenditure categories, the paper reveals that physical infrastructure investments enjoyed priority over long-term growthgenerating R\&D and human capital projects and that the allocation of EU funds did not reflect domestic development needs.
\end{abstract}

Keywords: EU cohesion policy, spending strategy, fund allocation, Southern Europe, Eastern Europe

* The author's research was supported by the MTA Post-Doctorate Research Program of the Hungarian Academy of Sciences 


\section{Introduction}

The European Union's cohesion policy aims at reducing regional disparities and enhancing competitiveness and economic growth in the less developed member states. Through this policy the EU provides generous transfers for those members that are lagging behind the most advanced countries. Over the decades, the Southern periphery (Greece, Italy, Ireland, Spain and Portugal) has received the greatest support, but the focus has shifted to the Eastern members since the 2004 enlargement.

Both of the peripheries suffered from the 2007-08 global financial and economic crises that gave a severe blow to their development. Facing multiple domestic problems such as economic decline, rising unemployment rates, budget deficit and debt, the cohesion policy gained an even greater significance for these states than before. By accelerating the spending of the funds, the EU tried to turn the cohesion policy into a tool that served as a buffer against economic downturn (Jacoby 2014). In spite of these efforts, the catch-up of the Southern periphery - except for Ireland - has been sluggish while the East is still lagging far behind the European core. Moreover, internal regional disparities have persisted both in the South and the East which suggests that the policy has failed to meet its stated goals.

Failing the declared targets gives rise to several potential explanations. On the one hand, the funds may have been insufficient to leave any visible impact on these economies. On the other hand, they might have been spent inefficiently or on underperforming projects. Another potential explanation for the lack of convergence between the EU core and periphery may be that the allocation of funds did not correspond to the development needs of the member states. To put it differently, it may be the case that the funds were spent on projects that were less likely to serve long-term economic catch-up. This calls for an inquiry into the spending strategies of the peripheral member states.

Although the European Union sets strict criteria on how the funds should be allocated to various expenditure categories, central governments still enjoy considerable freedom in choosing their spending priorities. The governments determine the final proportion of the EU funds across different objectives. Fund allocation within a member state thus reveals domestic spending preferences. The question is whether those preferences reflect domestic development needs or not.

The paper seeks to explore this issue by investigating the allocation of EU funds in the South and in the East in the previous (2007-13) and in the current programming period (2014-20) according to five spending categories (physical infrastructure, human capital, $R \& D$ and information technology, business support, and institution building) that constitute the backbone of the cohesion policy. These five dimensions represent those key areas along which the EU assesses the development needs of the member states. The paper shows that the EU's financial assistance 
has mostly been allocated for infrastructural investments, whereas funds dedicated to research and development and human capital projects - which are more likely to generate long-term economic growth - received less priority. The paper also reveals that the member states' spending strategies did not entirely follow their domestic development needs.

The paper proceeds as follows. First, it introduces the cohesion policy as a key developmental instrument for integrating the EU's peripheries with the core and formulates the research questions. Next, the paper highlights an empirical gap in the cohesion policy literature. Past research focused on the policy's consequences on domestic territorial administrative systems, its potential growth effects, political-institutional factors influencing its implementation, and determinants of fund absorption capacity. However, the spending strategies of the national governments set before each funding period have not been addressed so far. Before discussing the empirical results and their possible implications, the paper introduces the data sources and the applied analytical methods. The final section concludes and outlines some potential further lines of inquiry.

\section{Background and research questions}

The legal obligation in the Treaty of Rome (1957) to reduce economic disparities motivated the creation of the cohesion policy that dates back to 1975 when the European Regional Development Fund (ERDF) was launched. Even though the European Social Fund and the European Agricultural Guidance and Guarantee Fund had existed since 1958, the creation of the ERDF marks the birth of the cohesion policy (Allen 2005). Besides these financial instruments, which are usually referred to as the Structural Funds, another important building block of the policy is the Cohesion Fund (CF), which was established in 1994 to provide funding for large environmental and transport infrastructure projects in those member states where Gross National Income was below 90 percent of the EU average. ${ }^{1}$

The integration process - especially the creation of the European single market - was expected to aggravate economic disparities across the EU. The launch of the cohesion policy was therefore an attempt to "match the territorial scale of the response with the source of the economic problems" (Begg 2010, 81). EU policy-makers shared the view that financial assistance to the poorer member states would increase their growth rates (Frisina 2008) and would raise their market power. This seemed crucial for those countries that were the most exposed to the costs of integration. Some observers did not share these views though and considered the funds merely as side-payments to the relatively backward members to 'buy' their support for further economic integration (Leonardi 2005).

\footnotetext{
${ }^{1}$ Since the 2014-2020 programming period, the funds of the EU's cohesion policy are referred to as European Structural and Investment Funds (ESIF).
} 
In spite of the concerned voices, the EU has provided financial and technical assistance for the Southern and later on for the Eastern members to facilitate their integration into the European market. Funds distributed through the cohesion policy represent only a single element of the massive transformative toolkit of the EU with which it aimed to trigger state restructuring and at the same time intended to build domestic institutional capacities (Bruszt and Vukov 2015). Although some authors argue that especially in the case of the Eastern members assistance was mainly about maximizing the EU's own gains and minimizing the costs arising from enlargement (Jacoby 2010), both the scope and the depth of the external assistance suggests a nuanced EU approach with which it emerged as a unique transnational integration regime (Bruszt and McDermott 2014).

As Bruszt and Vukov (2015) observe, the EU applied different integration strategies towards the Southern and the Eastern periphery. While in the case of the South the EU initiated state restructuring by posing a variety of incentives that were expected to produce the desired outcome ("getting the incentives right"), in the East it intervened more directly (through conditionality, regular monitoring, and provision of technical assistance) and placed the emphasis on institutionbuilding ("getting the institutions right"). The funds of the cohesion policy served these purposes as well.

However, some key economic indicators which the cohesion policy was supposed to improve do not reflect these differentiated approaches. The Southern periphery's catch-up process has stalled, and its GDP per capita ${ }^{2}$ relative to the richest member states stands almost exactly where it was 20 years ago. In 2016, the level of GDP per head in the South reached 78 percent of the nine most developed member states ${ }^{3}$ while in 1995 this figure was 76 percent. $^{4}$ Although the East has shown signs of incremental convergence, the region is still far behind the core as its GDP per head stands at 66 percent of the most developed members.

The lasting consequences of the 2007-2008 economic crises increased the salience of the cohesion policy. First, the funds served as an external source of revenue for the shrinking state budgets. Second, the unfolding economic governance agenda of the EU placed serious limitations to overspending, which meant that the cohesion policy became the primary funding source of domestic development projects. These events highlight the importance of the central governments' spending strategies: the allocation of the EU funds to various expenditure categories shows the developmental priorities of the member states that may as well influence the funds' long term growth effects.

\footnotetext{
2 expressed in Purchasing Power Standards

${ }^{3}$ Austria, Belgium, Denmark, Finland, Germany, France, Netherlands, Sweden, United Kingdom. Luxemburg is excluded from the calculation because its extraordinarily high per capita GDP would lead to a misleading picture.

${ }^{4}$ Without Ireland. Source: the author's own calculation based on Eurostat data
} 
The above considerations constitute the background for the questions that this paper seeks to explore: (1) did the Southern and the Eastern members follow similar or different spending strategies; (2) and were their spending priorities in line with their domestic development needs?

\section{Spending strategies: a gap in the literature}

The vast majority of scholarly works that examine the cohesion policy focus on the old EU member states. Those studies can be classified into four distinct but related groups. An extensive literature explores the consequences of the funds on the domestic territorial administrative systems, while another line of inquiry estimates the effect of the funds on national and regional growth trends and analyzes their implications for regional disparities. Contributions closely related to the previous group examine the determinants of country- and regional-level absorption capacities and their consequences for economic growth. Finally, a limited number of works explain the domestic patterns of fund implementation and management by considering both economic and political aspects.

Works dedicated to the domestic institutional effects of the cohesion policy examine how the EU has empowered sub-national territorial units (see, for instance, Hooghe 1996; Bache and Jones 2000; Börzel 2002; Bourne 2003; Hughes, Sasse, and Gordon 2004b; Paraskevopoulos and Leonardi 2004; Baun and Marek 2006; Bachtler and McMaster 2007). Authors reach contradictory conclusions in that some argue that the EU has facilitated regionalization (Scherpereel 2010), while others show that those effects remained rather limited (Bruszt 2008).

Publications analyzing the effect of the funds on economic growth have also reached different conclusions. Some contend that the funds had an unconditional positive impact on growth (Bähr 2008; Becker, Egger, and von Ehrlich 2010; Cappelen et al. 2003), while others estimated a positive impact that depended on domestic institutional conditions (Ederveen, de Groot, and Nahuis 2006; Mohl and Hagen 2010), whereas several studies found negative or no impact at all (Boldrin and Canova 2003; Fagerberg and Verspagen 1996). Even though the results differ substantially, those scholars that apply the most sophisticated spatial econometric estimation techniques agree that EU grants have a differential economic impact on growth at the national and the sub-national level (Le Gallo, Dall'erba, and Guillain 2011; Kyriacou and Roca-Sagalés 2012).

The findings of the absorption capacity literature suggest that the negative relationship between economic growth and EU grants is related to the inferior institutional quality of the recipients. Ederveen and his co-authors (2006) showed that EU funds contributed to growth only in those countries that had an adequate institutional environment. This argument seems to travel to the sub-national level in that high levels of regional administrative capacity are associated with more effective fund implementation (Terracciano and Graziano 2016). Furthermore, a studyby 
Rodriguez-Pose and Garcilazo ( 2013) has established that EU funds had a marginal positive effect on growth only if the institutional quality of the recipient country was high. However, those member states and sub-national regions which are in the greatest need for external assistance are usually also the ones that have inferior institutional quality. The anticipated positive link between the growth effects of EU funds and institutional quality therefore leads to a paradoxical situation that the financial transfers fail to enhance growth precisely in those areas which, because of their backwardness, receive the greatest support. ${ }^{5}$

Finally, a growing literature focuses on the role of political circumstances in domestic fund management. Evidence from Western Europe suggests that national governments engage in vote seeking activities by channeling EU funds into those regions where their position is weaker (Bouvet and Dall'erba 2010; Dellmuth and Stoffel 2012). Similarly, Kemmerling and Bodenstein (2006) demonstrated that those sub-national regions received more EU grants where left-wing parties were stronger or where Eurosceptic parties proved more popular. However, Dellmuth (2011) found only mixed evidence for the vote-seeking behaviour of central governments. Recently, Charron (2016) has shown that both the autonomy of sub-national regions and their quality of regional government play a role in securing EU funds. Political manipulation with EU funds seems to characterize fund implementation in the Eastern member states as well (Bloom and Petrova 2013; Medve-Bálint 2017).

The above review of the literature reveals that both the growth effects of EU funds and the absorption capacity of the recipients may depend on economic, institutional and political factors. However, none of the scholarly works have so far examined the differences and similarities in how the member states allocate the available funds across key spending categories prior to each programming period. Scholars have not accounted for the spending strategies of the member states.

Although the European Commission sets mandatory earmarking requirements ${ }^{6}$ for certain expenditure categories, within these limitations national governments enjoy considerable freedom in establishing their spending priorities. Domestic preferences may differ on whether infrastructural investments, education and training programmes, or research and development projects receive more support. Cross-country variation in the proportion of EU funds allocated to

\footnotetext{
${ }^{5}$ According to the 2016 Worldwide Governance Indicators, the mean score for regulatory quality was nearly identical in the Southern (.89) and the Eastern periphery (.92), whereas in the most advanced EU economies (Austria, Belgium, Denmark, Finland, Germany, Luxembourg, the Netherlands, Sweden and the United Kingdom) the average score was nearly twice as high (1.70). Source: the author's own calculation based on the WGI dataset (available at http://info.worldbank.org/governance/wgi/index.aspx\#home).

${ }^{6}$ For instance, in the 2007-2013 programming period 60 percent of the funds spent in the eligible least developed regions (convergence regions) had to be spent on the so-called Lisbon objectives, while this share was 75 percent for funds spent in the more developed, yet eligible regions (regional competitiveness and employment objective). The Lisbon expenditures included investments into knowledge and innovation, energy efficiency, improving the business potential of small- and medium-sized enterprises and improving employability.
} 
these spending categories reflects the differences in domestic priorities. Member states may therefore follow diverse fund spending strategies.

Prioritizing a specific spending category over another has both political and economic significance. In political terms, national governments may use the funds to increase their popularity among the electorate by allocating funds for large-scale projects with high visibility, such as highway or railway construction. In economic terms, the anticipated developmental effects of the funds may also depend on the type of projects.

Although investing EU funds into physical (especially transport-related) infrastructure has been popular in the peripheral member states, this may lead to controversial growth effects. As Sloboda and Yao (2008) showed, investment in physical (transportation) infrastructure does not positively contribute to economic growth, at least not directly. While a comprehensive review of the literature revealed (Straub 2008) that most of the empirical studies found a significant, positive relationship between infrastructure investments and growth, there are some important caveats. First, improving transport connections between more developed and poor regions may enhance agglomeration effects in that easier access to the economic centre can facilitate the flow of labour and capital away from the periphery to the core. This is often referred to as a backwash effect which may stimulate growth in the centre but is disadvantageous for the laggard areas (Richardson 1976). A recent study (Cosci and Mirra 2018) examining the regional growth effects of the north-south highway in Italy found evidence for similar processes that had an ambiguous impact on the economic catch-up of the lagging behind southern regions with the centre and the north.

Second, if infrastructure investments improve transport inside poor regions, then they may contribute to the catch-up of areas that lag behind, but at the same time it may also slow down overall economic growth because the projects are realized at the expense of more developed areas. In a similar vein, Lakshmanan (2011) stresses that the impact of infrastructure investments on growth depends on a large number of intervening factors such as spatial agglomerations, interactions within and between economic sectors, technological change and trade patterns. Furthermore, Banister and Berechman (2001) argue that transport investments may contribute to economic growth only if an appropriate domestic economic environment meets with similarly favourable political and institutional conditions.

In contrast, empirical studies on the consequences of investments into human capital and research and development show a more straightforward and less conditional relationship with economic growth. As suggested by endogenous growth theory, technology and knowledge is characterized by increasing returns (Romer 1986; Lucas 1988). This implies that improving the level of human capital and support for R\&D activities may enhance economic growth also in the long run. Human capital investments have indeed been found to be positively related to long-term growth (Barro 2001), and they also tend to stimulate technological progress (Nelson and Phelps 1966). 
As Griffith and her co-authors (2004) showed, the returns to R\&D and human capital investments are higher in less developed countries than in more advanced economies. Further empirical findings (Bilbao-Osorio and Rodríguez-Pose 2004) suggest that a similar relationship applies in the case of the peripheral regions of the EU.

Based on the above evidence, a member state's fund spending strategy may substantially influence the economic effects of the EU grants. This is especially relevant in the post-crisis context in which growth-enhancing measures are more important than ever. While spending on physical infrastructure could potentially raise the popularity of the government, sustained positive developmental effects can be expected from less spectacular human capital and R\&D projects. Moreover, a mismatch between domestic development needs and fund allocation across various expenditure categories may fail to realize maximum returns on the investments. The following sections address these issues in detail. 


\section{Development needs and spending categories - concepts, hypothesis and data}

Prior to each funding period, the European Parliament and the European Council negotiates the total budget of the cohesion policy for the next programming cycle. Following the approval of the overall budget that indicates the total amount of funds available for each member state, the European Commission initiates consultations with the national governments about the specific domestic programmes to be funded. It is at this stage when the governments have to submit a development plan which identifies the spending priorities and the share that each prioritized area would receive from the funds. It is important to note that the amount of funds set aside for each country is fixed for every programming period; it is not possible to spend more than it is stipulated in the budget.

The Commission, which pays the certified expenditures and monitors project implementation, has to approve the national plans before member states begin spending the funds. The governments must determine the share of funds they intend to spend on the proposed programmes prior to the start of the programming period and before they receive any payments from the Commission. ${ }^{7}$ Domestic spending strategies are therefore revealed before every funding period and they remain fixed throughout.

In this paper, a member state's spending strategy refers to how the national development plans allocate the EU funds across the following categories: physical infrastructure; research, development and info-communication technology; human capital; business support; institution building. This is operationalized as the percentage share that each category takes from the total amount of funds allocated for the member state.

This work defines domestic development needs as the relative performance of the Southern and Eastern member states in the above five spending categories prior to each funding period. The lower the performance, the greater the relative need for developing that specific area. In order to measure relative development needs, each spending category is associated with three indicators that reveal the member state's performance before the two analyzed funding periods:

Indicators for physical infrastructure (funds for transport, environment and energy-related investments) where higher values reveal better performance:

- length of motorways per $1000 \mathrm{~km}^{2}$ (2006 and 2013)

- World Bank's quality of infrastructure index which is a composite indicator of the quality of trade- and transport-related infrastructure (e.g., ports, railroads, roads, information technology) (2007 and 2014)

\footnotetext{
${ }^{7}$ For further details on the process of planning and implementation of the cohesion policy please consult the European Commission's webpage: http://ec.europa.eu/regional_policy/how/index_en.cfm.
} 
- energy saving in final energy consumption in million tons of oil equivalent per million inhabitants (2006 and 2013)

Indicators for human capital (funds spent on educational and training programmes) where higher values demonstrate better performance:

- share of population (25-64 years) with tertiary education attainment (2006 and 2013)

- share of population (25-64 years) with upper secondary and post-secondary non-tertiary education (2006)

- participation rate of population (18-64 years) in education and training (2006 and 2013)

Indicators for research and development where higher values reflect better performance:

- patent applications to the European Patent Office per million inhabitants (2006 and 2013)

- total intramural R\&D expenditure of the government sector per inhabitant (2006 and 2013)

- total R\&D personnel as a percentage of total employed (2006 and 2012)

Indicators for business support (funds spent within this category mostly aim to generate jobs and enhance social inclusion):

- activity rate of females (15-64 years) (2006 and 2013)

- long-term unemployment in percentage of unemployment (2006 and 2013)

- long-term unemployment in percentage of active population (2006 and 2013)

While higher female activity rates indicate greater performance, the opposite is the case with the indicators of long-term unemployment.

Indicators for institutional quality (funds that aim to increase domestic institutional capacity) where higher values show better performance:

- Worldwide Governance Indicators of government effectiveness, regulatory quality and control of corruption (2006 and 2013).

For each spending category the relative development need of a member state is identified as follows. First, for every indicator countries are ranked on their performance. The top performer thus takes rank number one while the worst performer is ranked fifteenth. After the rankings have been assigned for every indicator they are aggregated. In this vein, the country scores in each spending category can range between 3 and 45 where higher values demonstrate greater relative development need or, in other words, inferior performance compared to the other Southern and Eastern member states. 
Finally, nonparametric tests of association ${ }^{8}$ are calculated in order to determine the extent to which development needs in each spending category correspond to the proportion of funds allocated to them. The assumption is that the member states allocate EU funds across the main spending categories according to the development needs of the different domestic segments. It is therefore expected that a government would allocate more funds (i.e., a higher share from the total EU grants) to those fields where the country's performance is comparatively low and less funds would be secured for those areas where the country is relatively close to the other member states. Thus the hypothesis is that the greater the relative development need in a specific field, the greater share of the funds will be allocated to that area. Hence, a positive association is expected between development needs and the share of funds devoted to the corresponding spending category.

The main limitation of this approach is that national governments may not compare their country's performance to others. Also, decisions on the spending priorities may not even be influenced by socio-economic indicators. Furthermore, it may also be the case that national performance is weak in each dimension thus every category could potentially become the prime target of the funds. Even in this case, however, the central government has to prioritize because the amount of EU transfers is fixed. It follows that the allocation of funds across the categories reflects the member states' spending preferences.

For each programming period the official EU documents apply different names to essentially the same expenditure categories. For instance, the European Commission grouped the committed expenses for 2000-06 into fourteen categories, while the documents for 2007-13 and 2014-20 listed the financial commitments along a similar but not identical typology. Table 1 shows how for the purposes of this paper these various expenditure categories in the official documents were grouped into the five key spending categories.

\footnotetext{
${ }^{8}$ Calculating Pearson's correlation coefficients for such a small number of observations $(\mathrm{N}=15)$ would produce misleading results. For this reason, Kendall's tau-b, which is a non-parametric test of association and is much more reliable for small samples, is applied.
} 
Table 1: Classification of the different expenditure categories into the five main spending categories

\begin{tabular}{|c|c|c|c|}
\hline $\begin{array}{l}\text { Main spending } \\
\text { category }\end{array}$ & Expenditure category in 2000-2006 & Expenditure category in $2007-2013$ & Expenditure category in 2014-2020 \\
\hline $\begin{array}{l}\text { Physical } \\
\text { infrastructure }\end{array}$ & $\begin{array}{l}\text { Transport infrastructure } \\
\text { Energy infrastructure } \\
\text { Environmental infrastructure } \\
\text { Planning and rehabilitation } \\
\text { Promoting the adaptation and development of } \\
\text { rural areas }\end{array}$ & $\begin{array}{l}\text { Transport } \\
\text { Energy } \\
\text { Environmental protection and risk prevention } \\
\text { Urban and rural regeneration }\end{array}$ & $\begin{array}{l}\text { Transport and energy networks } \\
\text { Low carbon economy } \\
\text { Climate change and risk prevention } \\
\text { Environment and resource efficiency }\end{array}$ \\
\hline $\begin{array}{l}\text { Research and } \\
\text { development }(\mathrm{R} \& D) \\
\text { and info- } \\
\text { communication } \\
\text { technology (ICT) }\end{array}$ & $\begin{array}{l}\text { Research, technological development and } \\
\text { innovation (RTDI) } \\
\text { Telecommunication infrastructure and } \\
\text { information society }\end{array}$ & $\begin{array}{l}\text { Research and technological development, } \\
\text { innovation and entrepreneurship } \\
\text { Information society }\end{array}$ & $\begin{array}{l}\text { Research and innovation } \\
\text { Information and communication technology }\end{array}$ \\
\hline Business support & $\begin{array}{l}\text { Assisting large business organizations } \\
\text { Assisting SMEs and the craft sector }\end{array}$ & $\begin{array}{l}\text { Increasing the adaptability of workers and } \\
\text { firms, enterprises and entrepreneurs } \\
\text { Improving access to employment and } \\
\text { sustainability } \\
\text { Culture } \\
\text { Tourism }\end{array}$ & $\begin{array}{l}\text { SME competitiveness } \\
\text { Employment and labour market }\end{array}$ \\
\hline Human capital & $\begin{array}{l}\text { Social inclusion } \\
\text { Developing education and vocational training } \\
\text { Social and public health infrastructure } \\
\text { Workforce flexibility, entrepreneurial activity } \\
\text { Positive labour market actions for women }\end{array}$ & $\begin{array}{l}\text { Improving the social inclusion of less-favoured } \\
\text { persons } \\
\text { Improving human capital } \\
\text { Investment in social infrastructure }\end{array}$ & $\begin{array}{l}\text { Social inclusion } \\
\text { Education and training }\end{array}$ \\
\hline $\begin{array}{l}\text { Institution building } \\
\text { and technical } \\
\text { assistance }\end{array}$ & $\begin{array}{l}\text { Labour market policy } \\
\text { Technical assistance and innovative actions }\end{array}$ & $\begin{array}{l}\text { Mobilisation for reforms in the fields of } \\
\text { employment and inclusion } \\
\text { Strengthening institutional capacity at national, } \\
\text { regional and local level } \\
\text { Technical assistance }\end{array}$ & $\begin{array}{l}\text { Efficient public administration } \\
\text { Technical assistance }\end{array}$ \\
\hline
\end{tabular}


Only eight of the eleven current Eastern European EU members ${ }^{9}$ participated in the 2000-06 programming cycle because Bulgaria and Romania joined the EU in 2007 while Croatia entered in 2013. But funding for those eight countries was also limited to 2004-06. These circumstances lead to serious difficulties with comparing the Southern and the Eastern members' spending strategies in 2000-06. This is the reason why the paper focuses on the 2007-13 and the 2014-20 programming cycles when each Southern and Eastern member received funds during the entire period.

\section{Empirical results and discussion}

This section first identifies differences and similarities in spending strategies, then it goes on to analyze whether fund allocation corresponded to the domestic development needs. Figure 1 displays the average shares ${ }^{10}$ of each category from the total EU financial support in the three programming periods. The figures reveal that spending on physical infrastructure has been treated as a priority in each budget cycle both in the East and in the South. At the same time, human capital projects and funds for business support have incrementally gained salience, while the share of funds on R\&D and info-communication increased in 2007-13 but decreased in 2014-20.

Figure 1 also reveals that the two country groups did not substantially differ from each other in terms of how the funds were prioritized across the main spending categories. The greatest differences appear in the share of funds allocated for physical infrastructure investments, and in this respect the spending preferences between the two peripheries differ the most in 201420. While in 2014-20 the East spends a much greater share of the funds on physical infrastructure than the South (47 percent vs. 29 percent), the South places more emphasis on business support relative to the East (26 percent vs. 16 percent).

Can the variation in the shares for physical infrastructure across the two country groups be attributed to the difference in the availability of the Cohesion Fund for the East and the South? As noted earlier, the Cohesion Fund exclusively finances physical infrastructure (transport and environment-related) projects. If it takes a high share from the total amount of EU funds, then it also drives up the share of funds spent on physical infrastructure. While the Eastern member states have received Cohesion Fund support in each programming period, in 2000-06 Ireland was eligible only until 2004 whereas Italy was not eligible at all. ${ }^{11}$ In $2007-$ 13 neither Ireland nor Italy received transfers from this financial instrument, whereas in 201420 only Greece and Portugal benefit from the Cohesion Fund.

\footnotetext{
${ }^{9}$ Czech Republic, Estonia, Hungary, Latvia, Lithuania, Poland, Slovakia, Slovenia

${ }^{10}$ The figures were calculated as the averages of the country-level shares of each spending category thus they are not biased by the spending strategy of those member states that received the highest amount of EU funds.

${ }^{11}$ On the results of the eligibility mid-term review in accordance with Article 2 of the Council Regulation (EC) No. 1164/1994 establishing a Cohesion Fund. Commission of the European Communities, Brussels, 24 March 2004. Available at http://eur-lex.europa.eu/LexUriServ/LexUriServ.do?uri=COM:2004:0191:FIN:EN:PDF.
} 
Figure 1: Share (\%) of the main spending categories from the total EU funds in the Southern and the Eastern EU member states

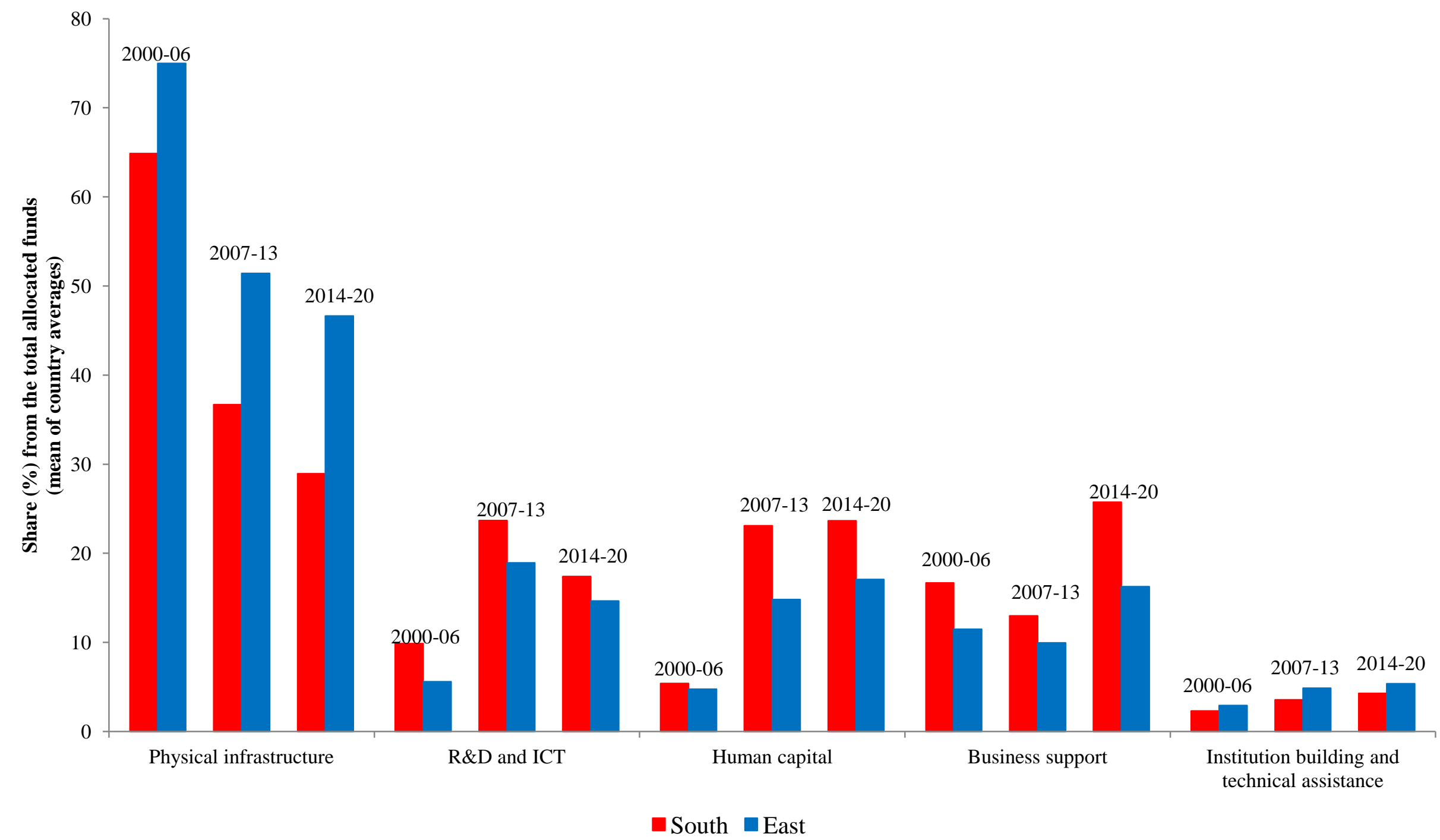

Source: the author's own calculation based on SWECO (2008), European Commission (2007) and ESIF data website (https://cohesiondata.ec.europa.eu/countries). 
Accordingly, in each budget period, the Cohesion Fund represented a larger portion of the EU funds in the Eastern periphery than in the South. On average, in 2000-06, 59 percent of the total external assistance for the East came through the Cohesion Fund whereas the share was only 23 percent in the Southern members. A similar pattern emerged in 2007-13: the CF represented 35 percent of the total funds allocated for the East compared to the 14 percent in the three eligible Southern states. ${ }^{12}$ In 2014-20 the average share of the Cohesion Fund from the total EU funds in the Eastern member states amounted to 30 percent whereas in the case of Greece and Portugal, the two eligible Southern countries, it reached 22 and 14 percent, respectively.

Interestingly, the growing difference between the East and the South in terms of the availability of the Cohesion Fund is not entirely reflected in the shares allocated for physical infrastructure projects. On the one hand, in both country groups infrastructure investments received priority. On the other hand, the Southern member states have maintained preference for spending a considerable share of the EU resources on physical infrastructure rather than placing greater emphasis on the other spending categories. This is puzzling in light of the economic crisis which generated grave and lasting problems of unemployment in the South that would seem to call for measures supporting human capital projects.

As for the relationship between development needs and the countries' spending strategies, Table 2 summarizes the results of the nonparametric tests of bivariate association between the measures of development needs in each spending category and the shares of funds allocated to the corresponding area. The plus signs highlight a significant positive relationship; the negative signs show a significant negative relationship, while the zeros reveal no relationship between the indicators.

The initial expectation was to find a positive association between the relative development needs and the share of funds. However, this only holds in the case of physical infrastructure and institution building, the two spending categories with the largest and lowest budgets, respectively. This suggests that more inferior domestic physical infrastructure is associated with greater share of EU funds spent on infrastructural investments. In a similar vein, lower institutional capacity is associated with higher share of funds devoted to institution building. However, this relationship does not apply to the other three spending categories, in spite of the fact that those are the areas which are most likely to produce positive development effects in the long run and are the most needed in the post-crisis context. What is more, fund allocation for

\footnotetext{
12 The country-level variation in the proportion of the Cohesion Funds from the total EU funds was low within the two country groups. For the eligible Southern countries the share of CF from the total funds ranged between 19 and 30 percent in 2000-06 and between 10 and 18 percent in 2007-13, while in the case of the Eastern periphery this figure varied between 53 and 65 percent in 2000-06 and between 33 and 36 percent in 2007-13. In 2014-20, the share of Cohesion Fund from the total EU funds is the lowest in Hungary (23 percent) and the highest in Bulgaria (33 percent) among the Eastern members.
} 
research and development reveals a counterintuitive pattern: the better a country's position, the higher share of EU funds it allocates for R\&D projects.

Table 2: The association between development needs and spending strategies

2007-2013

2014-2020

Physical infrastructure

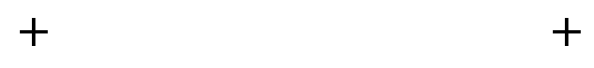

$(\tau=.456, \mathrm{p}<0.05)$

$(\tau=.651, \mathrm{p}<0.01)$

Research and development

$$
(\tau=-.449, \mathrm{p}<0.05)
$$

$(\tau=-.449, \mathrm{p}<0.05)$

Human capital

0

0

$(\tau=.049, \mathrm{p}>0.1)$

$(\tau=-.059, p>0.1)$

Business support

0

0

$(\tau=.243, \mathrm{p}>0.1)$

$(\tau=.202, \mathrm{p}>0.1)$

Institution building

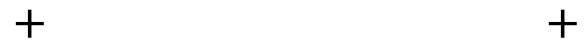

$(\tau=.502, \mathrm{p}<0.05)$

$(\tau=.495, \mathrm{p}<0.05)$

These simple tests of association do not explain why there is mixed evidence about the developmental impact of the EU funds across the member states. Nevertheless, they do suggest that spending strategies in the Eastern and the Southern periphery do not correspond to the domestic development needs. On the one hand, the dominance of physical infrastructure spending may be attributed to the fact that these investments are the most expensive ones. National governments thus prefer to dedicate the EU's resources to such projects instead of burdening the state budgets especially when fiscal discipline and tightening budgetary controls have become the dominant issues on the EU's current agenda. On the other hand, the completion of large infrastructural investments typically in the transport sector may yield immediate political gains for the governments because of their visibility and presumed popularity. These projects, however, may not contribute to economic growth in the long run precisely because of their adverse effects discussed earlier.

Finally, it also needs to be assessed whether total EU funds per capita are proportional to the overall (or absolute) development needs of the Eastern and Southern member states. Because some member states face challenges in nearly every dimension, they may receive proportionally 
more funds than those that enjoy a more favourable position. At the same time, low levels of development are also associated with low fund absorption capacity which implies that pouring money into the poorer member states may not improve their situation. The EU thus needs to strike a balance between minimizing the wasting of funds and maximizing their potential contribution to development.

In order to address the above question, the overall development need of the Southern and the Eastern member states were calculated by adding up their ranking scores on each spending category. This created a scale ranging from 15 to 225, where high scores indicate that the performance of the member state is low in nearly every aspect whereas a low value represents a good overall position relative to the others. These scores were then plotted against total EU funds per capita allocated to each member state in 2007-13 and 2014-20.

Based on the results displayed in Figure 2, the Southern and the Eastern member states demonstrate two distinct patterns. While per capita funds are rather proportional to the overall development needs of the Southern countries, in the case of the East the two variables suggest a negative relationship. This is mostly because Bulgaria and Romania, the two EU members facing the greatest development challenges, received the lowest per capita support in the Eastern periphery in both periods. On the one hand, the reason for this was the substantial delay in creating their domestic institutional background for fund administration. In fact, the European Commission decided to temporarily suspend the payments to the two countries because of grave irregularities in fund management and implementation (Spendzharova and Vachudova 2012). On the other hand, the low per capita EU support can also be explained by the anticipated low absorption capacity of these countries which, in turn, is a consequence of their level of backwardness.

Nevertheless, Figure 2 suggests that the EU allocated more funds to those Eastern members that demonstrated better overall performance relative to the others, while the Southern countries received support rather proportional to their development needs. The reason for the diverse approaches may reflect the EU's concerns about the Eastern members' fund absorption capacity ( Grabbe 2001; Bachtler and McMaster 2007; Ferry and McMaster 2013). It may be the case that the EU's priority was to maximize the absorption of funds and increase efficiency of spending (Hughes, Sasse, and Gordon 2004a). In the Eastern members the EU even encouraged the strengthening of the central administrations at the expense of creating sub-national administrative capacities for fund management (Bruszt 2008), but expectations about low fund absorption in the East did not materialize. In fact, both a qualitative (Bachtler, Mendez, and Oraže 2014) and a quantitative (Tosun 2014) analysis have shown that absorption rates in the Eastern members were higher than anticipated. 
Figure 2: Overall development need (2006 and 2013) and total per capita EU funds (2007-2013 and 2014-2020)

3000-

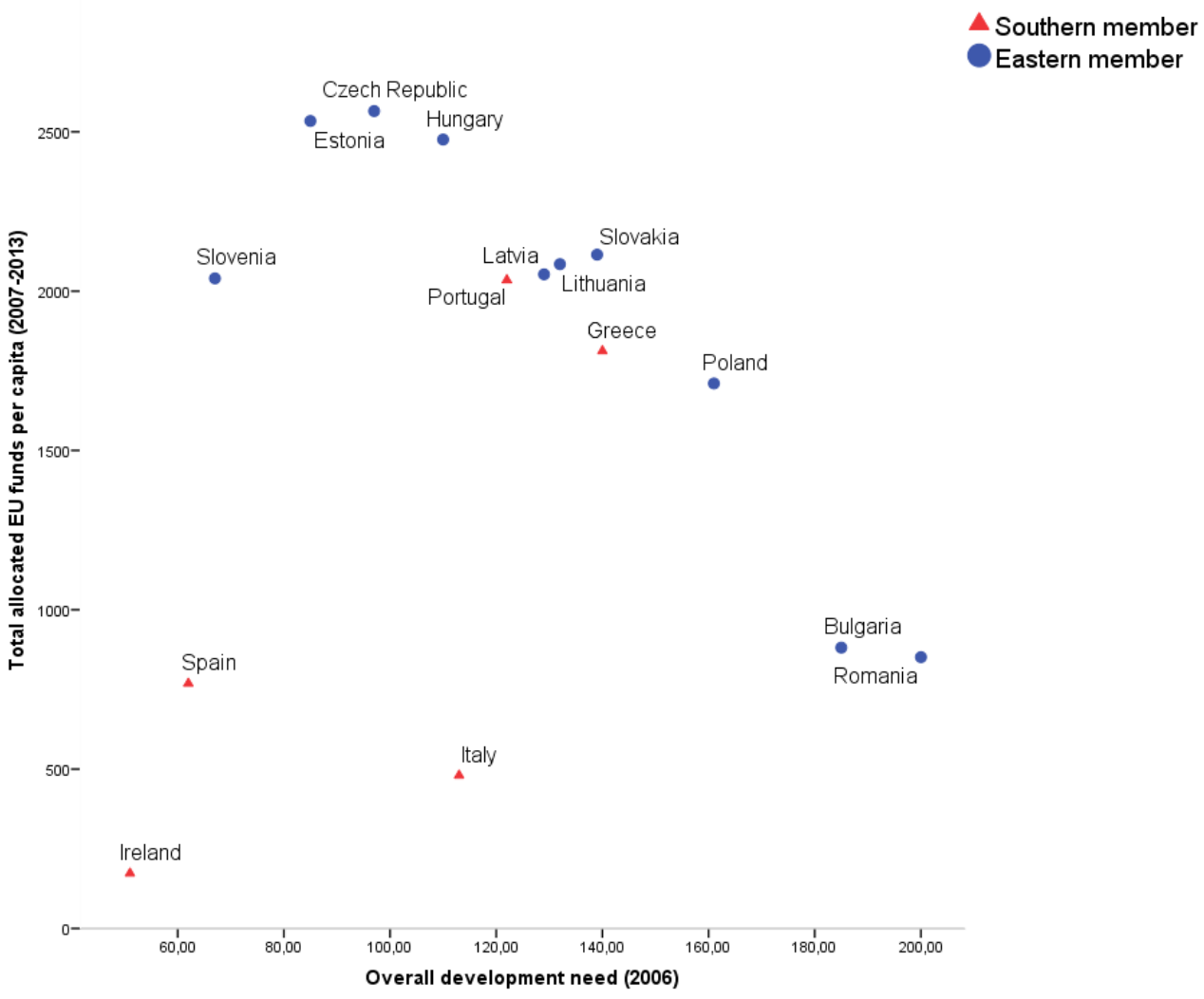




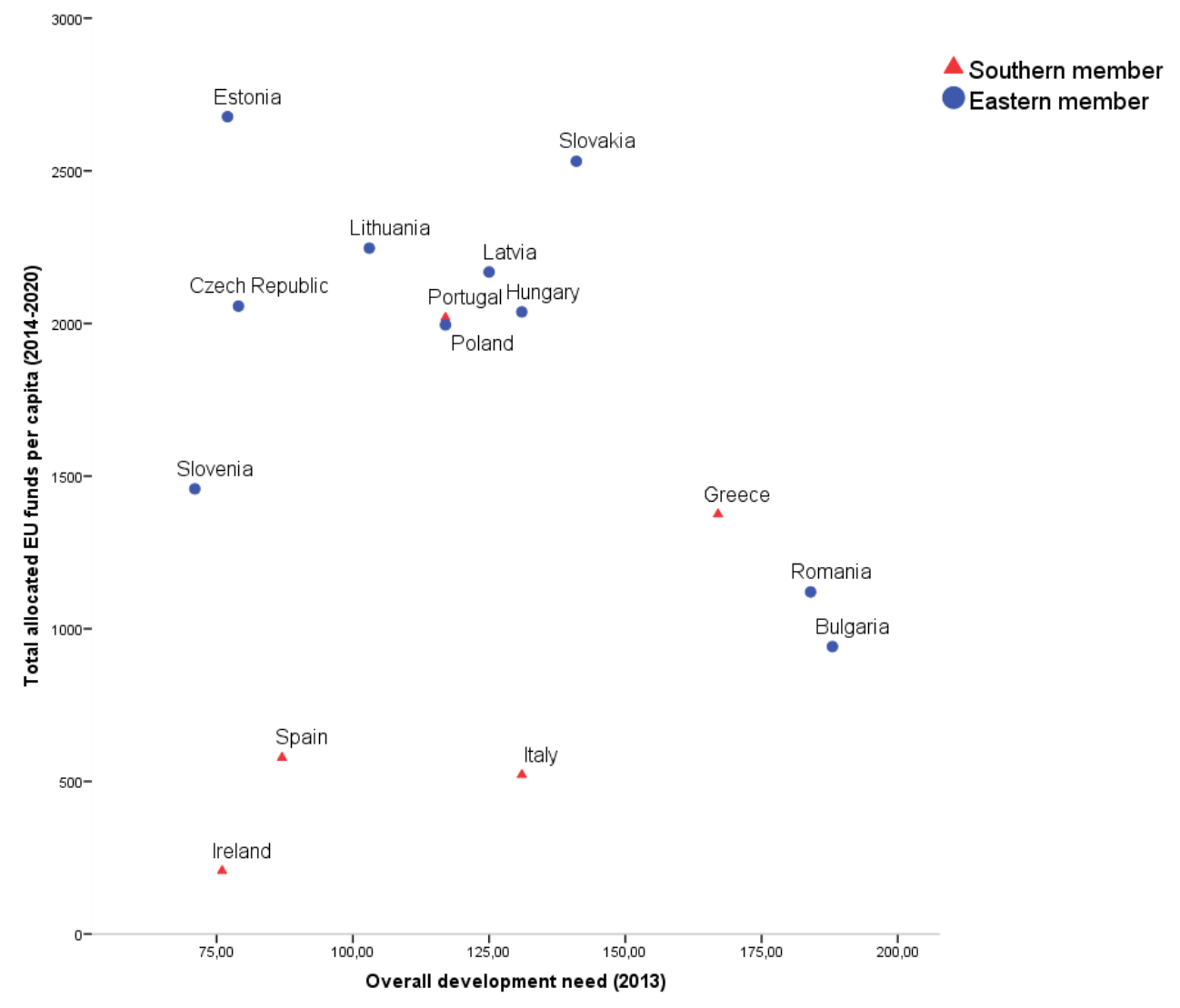

source: the author's own calculation based on European Commission (2007) and Eurostat and WGI data

\section{Conclusion}

The economic crisis in 2007-08 exposed the governments of the EU's Southern and Eastern periphery to shrinking state revenues, rising deficits and debt and a sharp fall in economic output. As these countries have traditionally been the greatest beneficiaries of the EU's cohesion policy, the funds allocated to them served as an important instrument to tackle these challenges. In these circumstances, the need to invest the EU funds in growth-generating projects gained even greater salience than before. To put it differently, the spending preferences of the national governments became a key issue in the post-crisis setting.

In line with this, the paper has sought to explore the spending strategies of the two peripheries. It highlighted how the national governments allocated the EU funds across five main spending categories in the last and the current programming cycles and, at the same time, it also investigated whether those spending preferences were in line with their domestic development needs. With this inquiry the paper aimed to contribute to the cohesion policy literature from a novel aspect: while past research has mostly concentrated on the determinants and consequences of fund absorption and implementation and how the policy shaped domestic state administration, 
the spending preferences of the member states have not been put under scrutiny. This is puzzling because the allocation of the funds to specific spending categories strikes the balance between domestic development objectives and may also influence the growth-generating effects of the funds.

The paper has found that both the Southern and the Eastern members have prioritized investments into physical infrastructure over other projects. In each observed period this spending category gained the largest - although declining - share from the EU funds even though the contribution of physical infrastructure investments to long-term economic growth may be questionable. In contrast, human capital and R\&D projects, which can be considered the two most important expenditure categories for future growth prospects, received less support.

The paper has also revealed that spending preferences were not entirely in line with domestic development needs. In the case of human capital and business support projects, there was no relationship between the share of funds and the measure of development need, while the analysis found an inverse association in the case of R\&D projects. Only the share of EU funds devoted to physical infrastructure and institution building seemed to correspond to domestic development needs. These findings confirm the bias in fund allocation towards physical investments. Finally, with respect to total funds per capita, the paper has found that while the Southern members received assistance proportional to their overall development need, a reverse relationship characterized the case of the Eastern countries.

The findings presented here supply some evidence for those studies that criticize the cohesion policy because of its ambiguous performance in generating economic growth in the peripheral EU members. Investing predominantly in physical infrastructure involves lower long-term growth prospects than financing human capital and R\&D projects, regardless of domestic absorption capacity and institutional quality. In this respect, the spending strategies of the peripheral member states suggest that they tend to misallocate the EU funds.

However, the empirical findings presented here raise some important questions that future research may address. First, the motivations for why national governments both in the South and the East kept prioritizing physical infrastructure investments over other projects with greater growth potentials needs to be explored. Second, the role of the EU in shaping domestic spending preferences also has to be clarified. All things considered, the misallocation of the funds is certainly not responsible for the lack of convergence between the EU core and periphery. However, the findings do suggest that by placing more emphasis on human capital and R\&D projects instead of physical investments, the cohesion policy funds may contribute to long-term economic growth more than they currently do. 


\section{References}

Allen, David. 2005. "Cohesion and the Structural Funds." In Policy-Making in the European Union, eds. Helen Wallace, William Wallace, and Mark Pollack. Oxford University Press, $213-42$.

Bache, I., and R. Jones. 2000. "Has EU Regional Policy Empowered the Regions? A Study of Spain and the United Kingdom." Regional \& Federal Studies 10(3): 1-20.

Bachtler, John, and Irene McMaster. 2007. "EU Cohesion Policy and the Role of the Regions: Investigating the Influence of Structural Funds in the New Member States." Environment and Planning C: Government and Policy 26(2): 398-427.

Bachtler, John, Carlos Mendez, and Hildegard Oraže. 2014. "From Conditionality to Europeanization in Central and Eastern Europe: Administrative Performance and Capacity in Cohesion Policy.” European Planning Studies 22(4): 735-57.

Bähr, Cornelius. 2008. "How Does Sub-National Autonomy Affect the Effectiveness of Structural Funds?" Kyklos 61(1): 3-18.

Banister, David, and Yossi Berechman. 2001. "Transport Investment and the Promotion of Economic Growth.” Journal of Transport Geography 9(3): 209-18.

Barro, Robert J. 2001. "Human Capital and Growth.” The American Economic Review 91(2): 12 17.

Baun, Michael, and Dan Marek. 2006. "Regional Policy and Decentralization in the Czech Republic." Regional and Federal Studies 16(4): 409-28.

Becker, Sascha O., Peter H. Egger, and Maximilian von Ehrlich. 2010. "Going NUTS: The Effect of EU Structural Funds on Regional Performance." Journal of Public Economics 94(910): 578-90.

Begg, Iain. 2010. "Cohesion or Confusion: A Policy Searching for Objectives.” Journal of European Integration 32(1): 77-96.

Bilbao-Osorio, Beñat, and Andrés Rodríguez-Pose. 2004. "From R\&D to Innovation and Economic Growth in the EU." Growth and Change 35(4): 434-55.

Bloom, Stephen, and Vladislava Petrova. 2013. "National Subversion of Supranational Goals: 'Pork-Barrel' Politics and EU Regional Aid." Europe-Asia Studies 65(8): 1599-1620.

Boldrin, Michele, and Fabio Canova. 2003. "Regional Policies and EU Enlargement." In European Integration, Regional Policy and Growth, eds. Bernhard Funck and Lodovico Pizzati. Washington D.C.: The World Bank, 33-94.

Börzel, Tanja A. 2002. States and Regions in the European Union: Institutional Adaptation in Germany and Spain. Cambridge University Press. 
Bourne, Angela K. 2003. "The Impact of European Integration on Regional Power." JCMS: Journal of Common Market Studies 41(4): 597-620.

Bouvet, Florence, and Sandy Dall'erba. 2010. "European Regional Structural Funds: How Large Is the Influence of Politics on the Allocation Process?" JCMS: Journal of Common Market Studies 48(3): 501-28.

Bruszt, László. 2008. "Multi-Level Governance - The Eastern Versions Emerging Patterns of Regional Developmental Governance in the New Member States." Regional and Federal Studies 18(5): 607-28.

Bruszt, László, and Gerald A. McDermott. 2014. "Introduction: The Governance of Transnational Regulatory Integration and Development." In Leveling the Playing Field: Transnational Regulatory Integration and Development, eds. László Bruszt and Gerald A. McDermott. Oxford University Press, 1-28.

Bruszt, László, and Visnja Vukov. 2015. “Transnationalizing States in Europe's Peripheries: European Integration and the Evolution of Economic State Capacities in the Southern and Eastern Peripheries of Europe." The Journal of Comparative Economic Studies 10: 6992.

Cappelen, Aadne, Fulvio Castellacci, Jan Fagerberg, and Bart Verspagen. 2003. "The Impact of EU Regional Support on Growth and Convergence in the European Union." JCMS: Journal of Common Market Studies 41(4): 621-44.

Charron, Nicholas. 2016. "Explaining the Allocation of Regional Structural Funds: The Conditional Effect of Governance and Self-Rule.” European Union Politics 17(4): 63859.

Cosci, Stefania, and Loredana Mirra. 2018. "A Spatial Analysis of Growth and Convergence in Italian Provinces: The Role of Road Infrastructure." Regional Studies 52(4): 516-27.

Dellmuth, Lisa Maria. 2011. "The Cash Divide: The Allocation of European Union Regional Grants.” Journal of European Public Policy 18(7): 1016-33.

Dellmuth, Lisa Maria, and Michael F. Stoffel. 2012. "Distributive Politics and Intergovernmental Transfers: The Local Allocation of European Union Structural Funds." European Union Politics 13(3): 413-33.

Ederveen, Sjef, Henri L.F. de Groot, and Richard Nahuis. 2006. "Fertile Soil for Structural Funds?A Panel Data Analysis of the Conditional Effectiveness of European Cohesion Policy." Kyklos 59(1): 17-42.

European Commission DG Regio. 2007. Cohesion Policy 2007-2013. National Strategic Reference Frameworks. Luxembourg: Office for Official Publications of the European Communities. http://ec.europa.eu/regional_policy/atlas2007/fiche/nsrf.pdf. 
Fagerberg, Jan, and Bart Verspagen. 1996. "Heading for Divergence? Regional Growth in Europe Reconsidered.” JCMS: Journal of Common Market Studies 34(3): 431-48.

Ferry, Martin, and Irene McMaster. 2013. "Cohesion Policy and the Evolution of Regional Policy in Central and Eastern Europe." Europe-Asia Studies 65(8): 1502-28.

Frisina, L. 2008. Understanding Regional Development: Absorption, Institutions and SocioEconomic Growth in the Regions of the European Union. Frankfurt am Main: Peter Lang.

Grabbe, Heather. 2001. "How Does Europeanization Affect CEE Governance? Conditionality, Diffusion and Diversity." Journal of European Public Policy 8(6): 1013-31.

Griffith, Rachel, Stephen Redding, and John Van Reenen. 2004. "Mapping the Two Faces of R\&D: Productivity Growth in a Panel of OECD Industries." Review of Economics and Statistics 86(4): 883-95.

Hooghe, Liesbet. 1996. Cohesion Policy and European Integration: Building Multi-Level Governance. Oxford University Press.

Hughes, James, Gwendolyn Sasse, and Claire Gordon. 2004a. "Conditionality and Compliance in the EU's Eastward Enlargement: Regional Policy and the Reform of Sub-National Government." JCMS: Journal of Common Market Studies 42(3): 523-51.

- 2004b. Europeanization and Regionalization in the EU's Enlargement to Central and Eastern Europe. Palgrave Macmillan.

Jacoby, Wade. 2010. "Managing Globalization by Managing Central and Eastern Europe: The EU's Backyard as Threat and Opportunity'.” Journal of European Public Policy 17(3): 416-432.

- 2014. "The EU Factor in Fat Times and in Lean: Did the EU Amplify the Boom and Soften the Bust?" Journal of Common Market Studies.

Kemmerling, Achim, and Thilo Bodenstein. 2006. "Partisan Politics in Regional Redistribution Do Parties Affect the Distribution of EU Structural Funds across Regions?" European Union Politics 7(3): 373-92.

Kyriacou, Andreas P., and Oriol Roca-Sagalés. 2012. "The Impact of EU Structural Funds on Regional Disparities within Member States." Environment and Planning C: Government and Policy 30(2): 267 - 281.

Lakshmanan, T. R. 2011. "The Broader Economic Consequences of Transport Infrastructure Investments." Journal of Transport Geography 19(1): 1-12.

Le Gallo, Julie, Sandy Dall'erba, and Rachel Guillain. 2011. "The Local versus Global Dilemma of the Effects of Structural Funds." Growth and Change 42(4): 466-90. 
Leonardi, Robert. 2005. Cohesion Policy in the European Union: The Building of Europe. New York: Palgrave Macmillan.

Lucas, Robert E. 1988. “On the Mechanics of Economic Development.” Journal of Monetary Economics 22(1): 3-42.

Medve-Bálint, Gergö. 2017. "Funds for the Wealthy and the Politically Loyal? How EU Funds May Contribute to Increasing Regional Disparities in East Central Europe." In $E U$ Cohesion Policy: Reassessing Performance and Direction, Regions and Cities, eds. John Bachtler, Sally Hardy, Peter Berkowitz, and Tatjana Muravska. London; New York: Routledge, 220-40.

Mohl, Philipp, and Tobias Hagen. 2010. "Do EU Structural Funds Promote Regional Growth? New Evidence from Various Panel Data Approaches." Regional Science and Urban Economics 40(5): 353-65.

Nelson, Richard R., and Edmund S. Phelps. 1966. "Investment in Humans, Technological Diffusion, and Economic Growth.” The American Economic Review 56(1/2): 69-75.

Paraskevopoulos, Christos J., and Robert Leonardi. 2004. "Introduction: Adaptational Pressures and Social Learning in European Regional Policy - Cohesion (Greece, Ireland and Portugal) vs. CEE (Hungary, Poland) Countries." Regional and Federal Studies 14(3): $315-54$.

Richardson, Harry W. 1976. "Growth Pole Spillovers: The Dynamics of Backwash and Spread." Regional Studies 10(1): 1-9.

Rodriguez-Pose, Andrés, and Enrique Garcilazo. 2013. Quality of Government and the Returns of Investment: Examining the Impact of Cohesion Expenditure in European Regions. OECD Publishing. OECD Regional Development Working Paper.

Romer, Paul M. 1986. "Increasing Returns and Long-Run Growth." The Journal of Political Economy: 1002-1037.

Scherpereel, John A. 2010. "EU Cohesion Policy and the Europeanization of Central and East European Regions." Regional and Federal Studies 20(1): 45-62.

Sloboda, Brian W., and Vincent W. Yao. 2008. "Interstate Spillovers of Private Capital and Public Spending.” The Annals of Regional Science 42(3): 505-18.

Spendzharova, Aneta B., and Milada Vachudova. 2012. "Catching Up? Consolidating Liberal Democracy in Bulgaria and Romania after EU Accession." West European Politics 35(1): $39-58$.

Straub, Stéphane. 2008. Infrastructure and Growth in Developing Countries: Recent Advances and Research Challenges. Policy Research Working Paper 4460. World Bank Development Research Department. 
SWECO. 2008. Final Report - ERDF and CF Regional Expenditure. Stockholm: SWECO International AB. Report prepared for the European Commission. http://ec.europa.eu/regional_policy/sources/docgener/evaluation/rado2_en.htm.

Terracciano, Brian, and Paolo R. Graziano. 2016. "EU Cohesion Policy Implementation and Administrative Capacities: Insights from Italian Regions." Regional \& Federal Studies 26(3): 293-320.

Tosun, Jale. 2014. "Absorption of Regional Funds: A Comparative Analysis." JCMS: Journal of Common Market Studies 52(2): 371-87. 


\section{Appendix 1: Shares of $\mathrm{EU}$ funds across the main spending categories by member states}

2000-06 shares (\%) from total allocation

\begin{tabular}{|c|c|c|c|c|c|}
\hline & R\&D and ICT & Human capital & $\begin{array}{l}\text { Business } \\
\text { support }\end{array}$ & Physical & $\begin{array}{l}\text { Institution } \\
\text { building and } \\
\text { technical } \\
\text { assistance }\end{array}$ \\
\hline Bulgaria & n.a. & n.a. & n.a. & n.a. & n.a. \\
\hline Czech Republic & 5,31 & 3,52 & 10,20 & 77,90 & 3,06 \\
\hline Estonia & 6,75 & 12,42 & 6,52 & 70,97 & 3,33 \\
\hline Ireland & 12,29 & 0,00 & 3,03 & 76,69 & 5,39 \\
\hline Greece & 9,55 & 8,26 & 10,25 & 67,64 & 2,53 \\
\hline Spain & 8,66 & 5,42 & 10,45 & 75,28 & 0,19 \\
\hline Italy & 10,44 & 1,97 & 37,52 & 47,68 & 2,39 \\
\hline Latvia & 4,07 & 3,18 & 13,31 & 77,53 & 1,91 \\
\hline Lithuania & 6,09 & 7,07 & 10,24 & 73,10 & 3,50 \\
\hline Hungary & 7,03 & 7,12 & 11,34 & 69,60 & 2,43 \\
\hline Poland & 3,89 & 2,70 & 11,69 & 79,86 & 1,86 \\
\hline Portugal & 8,34 & 11,36 & 22,07 & 57,05 & 1,06 \\
\hline Romania & n.a. & n.a. & n.a. & n.a. & n.a. \\
\hline Slovenia & 9,02 & 0,00 & 18,15 & 68,07 & 4,76 \\
\hline Slovakia & 2,59 & 1,97 & 10,27 & 82,75 & 2,42 \\
\hline $\begin{array}{l}\text { Mean share } \\
\text { East }\end{array}$ & 5,59 & 4,75 & 11,47 & $\mathbf{7 4 , 9 7}$ & 2,91 \\
\hline $\begin{array}{l}\text { Mean share } \\
\text { South }\end{array}$ & $\mathbf{9 , 8 6}$ & $\mathbf{5 , 4 0}$ & 16,66 & 64,87 & 2,31 \\
\hline
\end{tabular}

2007-13 shares (\%) from total allocation

\begin{tabular}{|c|c|c|c|c|c|}
\hline & R\&D and ICT & Human capital & $\begin{array}{l}\text { Business } \\
\text { support }\end{array}$ & $\begin{array}{l}\text { Physical } \\
\text { infrastructure }\end{array}$ & $\begin{array}{l}\text { Institution } \\
\text { building }\end{array}$ \\
\hline Bulgaria & 10,86 & 9,83 & 11,55 & 57,48 & 10,28 \\
\hline Czech Republic & 19,19 & 11,91 & 11,16 & 52,59 & 5,15 \\
\hline Estonia & 21,51 & 20,01 & 11,01 & 44,87 & 2,60 \\
\hline Ireland & 25,68 & 42,64 & 6,96 & 23,12 & 1,60 \\
\hline Greece & 17,21 & 16,97 & 14,18 & 48,57 & 3,07 \\
\hline Spain & 23,03 & 7,03 & 18,99 & 48,66 & 2,28 \\
\hline Italy & 27,97 & 15,78 & 17,22 & 34,29 & 4,74 \\
\hline Latvia & 19,92 & 17,75 & 6,24 & 51,96 & 4,12 \\
\hline Lithuania & 19,76 & 17,91 & 10,21 & 46,57 & 5,55 \\
\hline Hungary & 16,92 & 20,85 & 7,46 & 50,32 & 4,45 \\
\hline Poland & 21,71 & 11,32 & 9,30 & 53,12 & 4,55 \\
\hline Portugal & 24,51 & 33,12 & 7,57 & 28,77 & 6,04 \\
\hline Romania & 11,84 & 11,67 & 12,23 & 58,95 & 5,32 \\
\hline Slovenia & 26,69 & 11,14 & 11,09 & 48,29 & 2,79 \\
\hline Slovakia & 20,99 & 15,88 & 9,18 & 50,08 & 3,87 \\
\hline Mean share & 18,94 & 14,83 & 9,94 & 51,42 & 4,87 \\
\hline
\end{tabular}




\begin{tabular}{|c|c|c|c|c|c|}
\hline East & & & & & \\
\hline $\begin{array}{l}\text { Mean share } \\
\text { South }\end{array}$ & 23,68 & 23,11 & 12,98 & 36,68 & 3,55 \\
\hline 2014-20 shares ( & o) from total alloc & ation & & & \\
\hline & R\&D and ICT & Human capital & $\begin{array}{l}\text { Business } \\
\text { support }\end{array}$ & $\begin{array}{l}\text { Physical } \\
\text { infrastructure }\end{array}$ & $\begin{array}{l}\text { Institution } \\
\text { building }\end{array}$ \\
\hline Bulgaria & 7,12 & 16,67 & 15,07 & 53,18 & 7,96 \\
\hline Czech Republic & 15,94 & 17,93 & 10,09 & 51,23 & 4,81 \\
\hline Estonia & 20,57 & 22,66 & 19,68 & 30,63 & 6,46 \\
\hline Ireland & 22,80 & 31,68 & 30,95 & 13,08 & 1,48 \\
\hline Greece & 11,38 & 14,33 & 18,88 & 49,55 & 5,86 \\
\hline Spain & 23,78 & 17,76 & 23,95 & 31,38 & 3,13 \\
\hline Italy & 16,70 & 23,84 & 24,62 & 28,17 & 6,67 \\
\hline Latvia & 14,59 & 21,29 & 9,83 & 51,57 & 2,72 \\
\hline Lithuania & 13,82 & 17,97 & 18,40 & 44,37 & 5,45 \\
\hline Hungary & 14,06 & 17,75 & 26,22 & 37,63 & 4,35 \\
\hline Poland & 17,12 & 12,24 & 14,30 & 52,64 & 3,69 \\
\hline Portugal & 12,39 & 30,63 & 30,27 & 22,48 & 4,23 \\
\hline Romania & 6,71 & 14,59 & 10,74 & 61,68 & 6,28 \\
\hline Slovenia & 17,66 & 14,96 & 27,10 & 34,22 & 6,05 \\
\hline Slovakia & 19,01 & 14,54 & 11,19 & 49,33 & 5,93 \\
\hline $\begin{array}{l}\text { Mean share } \\
\text { East }\end{array}$ & 14,66 & 17,06 & 16,26 & 46,65 & 5,37 \\
\hline $\begin{array}{l}\text { Mean share } \\
\text { South }\end{array}$ & 17,41 & 23,65 & 25,73 & 28,93 & 4,27 \\
\hline
\end{tabular}

Source: the author's own calculation 


\section{Appendix 2: Per capita EU funds on the main spending categories by countries}

2000-2006 per capita allocation in EUR (pop. data: 1999)

\begin{tabular}{|c|c|c|c|c|c|}
\hline Bulgaria & $\begin{array}{l}\text { R\&D and ICT } \\
\text { n.a. }\end{array}$ & $\begin{array}{l}\text { Human capital } \\
\text { n.a. }\end{array}$ & $\begin{array}{l}\text { Business } \\
\text { support } \\
\text { n.a. }\end{array}$ & $\begin{array}{l}\text { Physical } \\
\text { infrastructure } \\
\text { n.a. }\end{array}$ & $\begin{array}{l}\text { building and } \\
\text { technical } \\
\text { assistance } \\
\text { n.a. }\end{array}$ \\
\hline Czech Republic & 10,72 & 7,11 & 20,57 & 157,14 & 6,17 \\
\hline Estonia & 32,47 & 59,75 & 31,37 & 341,36 & 16,02 \\
\hline Ireland & 83,40 & 0,00 & 30,60 & 520,28 & 36,59 \\
\hline Greece & 164,10 & 141,90 & 196,48 & 1161,79 & 43,49 \\
\hline Spain & 87,13 & 54,48 & 105,09 & 757,07 & 1,94 \\
\hline Italy & 34,20 & 6,45 & 122,88 & 156,16 & 7,84 \\
\hline Latvia & 18,49 & 14,45 & 60,43 & 351,99 & 8,66 \\
\hline Lithuania & 24,28 & 28,18 & 40,84 & 291,45 & 13,93 \\
\hline Hungary & 18,64 & 18,88 & 36,43 & 184,50 & 6,45 \\
\hline Poland & 10,56 & 7,34 & 31,75 & 216,96 & 5,05 \\
\hline Portugal & 135,52 & 184,51 & 358,58 & 926,94 & 17,23 \\
\hline Romania & n.a. & n.a. & n.a. & n.a. & n.a. \\
\hline Slovenia & 17,82 & 0,00 & 35,87 & 134,48 & 9,40 \\
\hline Slovakia & 6,57 & 5,01 & 26,07 & 210,06 & 6,14 \\
\hline East & 17,44 & 17,59 & 35,42 & 235,99 & 8,98 \\
\hline South & 100,87 & $\mathbf{7 7 , 4 7}$ & 162,73 & 704,45 & 21,42 \\
\hline
\end{tabular}

2007-2013 per capita allocation in EUR (pop. data: 2006)

\begin{tabular}{|c|c|c|c|c|c|}
\hline & R\&D and ICT & Human capital & $\begin{array}{l}\text { Business } \\
\text { support }\end{array}$ & $\begin{array}{l}\text { Physical } \\
\text { infrastructure }\end{array}$ & $\begin{array}{l}\text { Institution } \\
\text { building }\end{array}$ \\
\hline Bulgaria & 95,68 & 86,62 & 101,77 & 506,59 & 90,62 \\
\hline Czech Republic & 492,12 & 305,62 & 286,30 & 1348,93 & 132,08 \\
\hline Estonia & 545,01 & 507,05 & 279,06 & 1137,12 & 65,85 \\
\hline Ireland & 44,37 & 73,69 & 12,02 & 39,96 & 2,77 \\
\hline Greece & 311,85 & 307,47 & 257,00 & 880,22 & 55,62 \\
\hline Spain & 177,11 & 54,08 & 146,04 & 374,12 & 17,56 \\
\hline Italy & 134,35 & 75,80 & 82,70 & 164,68 & 22,78 \\
\hline Latvia & 409,00 & 364,47 & 128,12 & 1066,64 & 84,63 \\
\hline Lithuania & 412,03 & 373,39 & 212,90 & 970,84 & 115,62 \\
\hline Hungary & 418,81 & 516,22 & 184,59 & 1245,86 & 110,25 \\
\hline Poland & 371,31 & 193,56 & 159,10 & 908,61 & 77,88 \\
\hline Portugal & 498,64 & 673,81 & 153,98 & 585,25 & 122,87 \\
\hline Romania & 100,78 & 99,32 & 104,16 & 501,87 & 45,27 \\
\hline Slovenia & 544,53 & 227,19 & 226,26 & 985,11 & 56,86 \\
\hline Slovakia & 443,80 & 335,72 & 194,05 & 1058,93 & 81,82 \\
\hline East & 383,31 & 300,92 & 187,63 & 973,05 & 86,09 \\
\hline
\end{tabular}




\begin{tabular}{|c|c|c|c|c|c|}
\hline South & 233,26 & 236,97 & 130,35 & 408,85 & 44,32 \\
\hline \multicolumn{6}{|c|}{ 2014-2020 per capita allocation in EUR (pop. data: 2013) } \\
\hline & R\&D and ICT & Human capital & $\begin{array}{l}\text { Business } \\
\text { support }\end{array}$ & $\begin{array}{l}\text { Physical } \\
\text { infrastructure }\end{array}$ & $\begin{array}{l}\text { Institution } \\
\text { building }\end{array}$ \\
\hline Bulgaria & 67,02 & 156,98 & 141,93 & 500,79 & 74,98 \\
\hline Czech Republic & 327,77 & 368,73 & 207,54 & 1053,80 & 98,97 \\
\hline Estonia & 550,60 & 606,74 & 527,02 & 819,97 & 173,01 \\
\hline Ireland & 47,27 & 65,67 & 64,15 & 27,12 & 3,07 \\
\hline Greece & 156,58 & 197,14 & 259,67 & 681,51 & 80,60 \\
\hline Spain & 137,42 & 102,63 & 138,39 & 181,28 & 18,06 \\
\hline Italy & 87,09 & 124,28 & 128,37 & 146,87 & 34,77 \\
\hline Latvia & 316,38 & 461,75 & 213,26 & 1118,40 & 58,99 \\
\hline Lithuania & 310,55 & 403,68 & 413,34 & 996,96 & 122,38 \\
\hline Hungary & 286,42 & 361,73 & 534,21 & 766,69 & 88,64 \\
\hline Poland & 341,62 & 244,30 & 285,33 & 1050,30 & 73,68 \\
\hline Portugal & 250,18 & 618,64 & 611,41 & 454,05 & 85,47 \\
\hline Romania & 75,19 & 163,53 & 120,36 & 691,19 & 70,35 \\
\hline Slovenia & 257,55 & 218,24 & 395,28 & 499,15 & 88,23 \\
\hline Slovakia & 481,13 & 368,15 & 283,31 & 1248,56 & 150,09 \\
\hline East & 301,42 & 335,38 & 312,16 & 874,58 & 99,93 \\
\hline South & 135,71 & 221,67 & 240,40 & 298,17 & 44,39 \\
\hline
\end{tabular}

Source: the author's own calculation 